\title{
Article
}

\section{The effectiveness of exercise on gait, turning and falls in individuals with Parkinson's disease: A Scoping Review}

Khobkhun, Fuengfa, Khacharoen, Suweena, Tretriluxana, Jarugool and Richards, James

Available at http://clok.uclan.ac.uk/36747/

Khobkhun, Fuengfa, Khacharoen, Suweena, Tretriluxana, Jarugool and Richards, James ORCID: 0000-0002-4004-3115 (2021) The effectiveness of exercise on gait, turning and falls in individuals with Parkinson's disease: A Scoping Review. International Journal of Pharmaceutical Research, 13 (2). ISSN 0975-2366

It is advisable to refer to the publisher's version if you intend to cite from the work. 10.31838/ijpr/2021.13.02.166

For more information about UCLan's research in this area go to

http://www.uclan.ac.uk/researchgroups/ and search for < name of research Group>.

For information about Research generally at UCLan please go to http://www.uclan.ac.uk/research/

All outputs in CLoK are protected by Intellectual Property Rights law, including Copyright law. Copyright, IPR and Moral Rights for the works on this site are retained by the individual authors and/or other copyright owners. Terms and conditions for use of this material are defined in the policies page.

\section{CLoK}

Central Lancashire online Knowledge www.clok.uclan.ac.uk 


\title{
Type: A Scoping Review
}

\section{The effectiveness of exercise on gait, turning and falls in individuals with Parkinson's disease: $A$ Scoping Review}

Fuengfa Khobkhuna*, Suweena Khacharoena, Jarugool Tretriluxanaa, Jim Richardsb a Department of Physical Therapy, Faculty of Physical Therapy, Mahidol University, Salaya, NaKhon Pathom, Thailand b Allied Health Research unit, School of Sport and Health Sciences, University of Central Lancashire, Preston, UK

*Corresponding author: Dr. Fuengfa Khobkhun: Faculty of Physical Therapy, Mahidol University, Salaya, Nakhon Pathom73170, Thailand

E-mail address: fuengfa.kho@mahidol.edu

\begin{abstract}
Purpose: To determine the level of evidence for exercise based rehabilitation and its effect on gait and turning performance which have been associated with a reduced incidence of falls.

Methods and analysis: The following databases were searched systematically: Cochrane Library, Physiotherapy Evidence Database (PEDro), Scopus, Web of Science and PubMed. Articles comparing the effects of exercise-based treatment as an experimental intervention with a non-physiotherapy intervention as the control were described using the synthesis method.

Results: Twelve out of the twenty-seven studies eligible for inclusion focussed explicitly on exercise-based treatment for gait and turning related to falls prevention in individuals with PD. Studies included specific exercise programmes relevant to locomotion performance, Tai Chi and dance therapy which have all been shown to improve temporal, spatial and kinematic parameters in gait and turning, leading to improvements in fall parameters.
\end{abstract}

Conclusion: This review evinces that Tai Chi, dance therapy and specific exercise programmes can result in improvements in turning performance and may reduce the likelihood of falls in individuals with $\mathrm{PD}$, however further research is required to explore the relationship between the benefits of exercise-based interventions on functional mobility and falls incidence.

\section{Keywords: Parkinson's disease; gait; turning; falls; scoping reviews}

\section{Introduction}

Gait disorders are one of the most common presentations in individuals with Parkinson's disease (PD). ${ }^{1,2}$ Individuals with PD have a gait pattern characterised by freezing, festination, hesitant, shuffling steps that are short and quick. ${ }^{3},{ }^{4}$ Normally, human gait composes of straight walking and turning. Turning is a complex locomotion, to turn towards and align with a new direction ${ }^{5,6}$ is a coordinated process that is characterised by a top-down sequence of the reorientation of body segments that starts 
with the eyes and head and is followed by the trunk and ends with the feet. ${ }^{7-9}$ Prior to changing direction, healthy adults usually shift their gaze in the direction of the turn, and this anticipatory gaze behaviour is believed to represent an important part of the eye, head and body coordinated process. ${ }^{7-10}$ This is not represented in individuals with PD, who demonstrate a loss of axial rotation and decrease in segmental coordination producing an en-bloc turn rather than a top-down sequence. ${ }^{5,11-13}$

Difficulties in gait and turning due to changes in postural control are also problematic, and falls frequently occur during the mid to latter stages of PD. Individuals with PD who had experience of falls, have a fear of falling and change their activities of daily living in an attempt to avoid fall-related activities. ${ }^{14,15}$ Nowadays, Levodopa therapy and deep brain stimulation are widely prescribed treatments for improving functional mobility in PD. However, the effectiveness of these treatments is equivocal. ${ }^{3,16}$ Although the literature suggests there are benefits of Levodopa therapy and deep brain stimulation in improving mobility including gait, turning and falling performances, evidence also suggests there are adverse effects of long-term use of Levodopa therapy. ${ }^{1618}$ Combining medications with exercise physiotherapy has shown promise in improving functional movement and has been recommended for neuro-rehabilitation, and different exercise programmes have been designed specifically for individuals with PD. ${ }^{3}$ 19-25 Consequently, a physiotherapy rehabilitation approach has been recommended to compliment the use of Levodopa for individuals with PD. ${ }^{16-18}$ Nevertheless, there is a general lack of evidence in terms of the effectiveness of rehabilitation which focuses on gait, turning and falling according to a systematic review. ${ }^{26-30}$ Therefore, this scoping review was aimed to determine the effects of exercise-based rehabilitation to improve turning deficits and their relevance to falls prevention in individuals with PD. A comprehensive review of exercise-based interventions associated with improving gait, turning and falls prevention in individuals with PD is needed to help researchers better understand common approaches and guide the translation of research to physiotherapist in clinical settings.

\section{Methods and procedure}

The purposes of this scoping review were to identify, understand, summarise and disseminate findings from a broad body of literature about the effects of exercise on improving gait, turning and falls prevention in individuals with PD. The protocol of this scoping review was based on the framework outlined by Arksey and O'Malley ${ }^{31}$ and PRISMA extension for scoping reviews. ${ }^{32}$ The methodology included five steps: (1) identifying the research question, (2) identifying studies relevant to the research question, (3) selecting studies, (4) charting of information and data within the included studies and (5) collating, summarising and reporting the results.

Step 1: Identifying the research question: The research question that guided this scoping review was "Are rehabilitation exercises based on gait and turning effective for falls prevention in individuals with PD?" To formulate a structure for the research question, the PICOT method was employed to address the search strategy design. The population was "idiopathic PD stage 1 to 4 by Hoehn and Yahr staging scale", as defined by study authors. For the intervention, "exercised-based rehabilitation" was defined as activity that is planned, structured, repetitive and purposive for improvement of turning and falls problems, and the control group was defined as "usual care, education or medication only", i.e. not receiving any physiotherapy. The outcome was "gait, turning and falls outcomes", defined as those relating to gait, turning and falling including both 
clinical and laboratory outcomes, i.e. Timed Up and Go test (TUG), turning time, turning steps, turning movement patterns, fall measurements. The time frame adopted was from 2010 to 2020 .

Step 2: Identifying relevant studies: To ensure a comprehensive search of the literature, the following licensed databases were searched for peer-reviewed articles: Cochrane Central Register of Controlled Studies (CENTRAL) (The Cochrane Library; last searched August 2020), PubMed (2010 to August 2020), PEDro (2010 to August 2020), Scopus (last search August 2020), Web of Science (2010 to August 2020). Hand searching was included for more relevant citations to ensure that a comprehensive search was conducted. The keywords were then identified based on the review of the relevant literature and ultimately the consensus of three of the authors. The keywords explored three main categories: (1) Parkinson's disease, (2) physiotherapy or intervention or exercise or rehabilitation or physical therapy and (3) gait, turning and falling (the logical structure is included in the supplementary information).

Step 3: Study selection and identification: After completing all database searches, the citations were compiled and entered into EndNote X9 bibliographic manager, where duplicate citations were removed. From the search results, two review authors independently read the titles and screened the abstracts of potentially relevant studies. They eliminated obviously irrelevant studies, with the full paper being obtained if the abstract did not provide sufficient information to determine eligibility for inclusion in the review. Based on our inclusion criteria (participants, type of interventions, outcome and comparator), two review authors independently categorised these studies as "relevant", "irrelevant" or "possibly relevant". If there was any disagreement, it was resolved by referring to a third review author. Furthermore, authors of potentially eligible studies were contacted for further information if the details of their study were unclear.

Step 4: Charting the information and data: Two review authors independently assessed the eligible papers or abstracts for study details and outcome data. These were then validated through discussion, and any discrepancies were resolved by consensus. Study details were recorded on a standard study description form, which included the following: authors, year of publication, source of origin, aims, sample size, methodology, intervention type and comparator, concept, duration of the intervention and eligibility criteria. Additionally, authors of any eligible unpublished studies were contacted to ask if further details and data for their study could be provided.

Step 5: Collating, summarising and reporting: Following data extraction, a narrative synthesis was conducted to describe the articles. Overall, an exercise-based rehabilitation focussing on improving gait, turning and falling, met the criteria that was used to identify, summarise and disseminate the research findings (e.g. exercise programme, type of exercise and duration of exercise).

\section{Results}

A total of 4831 results were retrieved from database searching and additional sources. Duplicated results ( $\mathrm{n}=435)$ were removed, leaving 4396 records were eligible for screening. After screening the abstracts, 4332 papers were excluded following the five criteria: (1) populations were not diagnosed with idiopathic PD; (2) the experimental 
intervention was not a rehabilitation program or exercise to facilitate turning capacity; (3) the main or secondary outcome measures were not related to falls; (4) the papers were review articles, case studies, proceedings, opinion, book guidelines or were not randomized controlled trial studies; (5) contained insufficient or unclear information regarding the intervention or measurement. Additionally, a further 37 papers were excluded after the assessment for inclusion due to confounding interventions, unable to access the full-paper, records in clinical trial database or papers not written in English. The remaining 27 articles were read, of these 12 papers matched all the criteria and the papers were included in the review which were published between 2013 and 2019 (see Table 1 for summary).

\subsection{Details of study design of the reviewed articles}

The study design for all papers was randomized controlled trials. Study location from these papers were took placed in the United States $(n=4)$, Poland $(n=2)$, China $(n=1)$, Korea $(n=1)$, Canada $(n=1)$, United Kingdom $(n=1)$, Australia $(n=1)$ and Italy $(n=1)$. Participants in these studies were diagnosed with $\mathrm{PD}^{13,33-35}$ or idiopathic PD. ${ }^{36-42}$ The number of participants ranged from 4 to 76 (6-49 men and $7-32$ women). Severity of PD was varied through all stages. However, most of the studies selected participants with mild to moderate severity, with an age range of 62.0 to 73.4 years.

Table 1 shows a summary of the exercise prescription in included papers and Table 2 described the objective, outcome measurements and main findings of the studies. In summary, primary and secondary outcomes were related to gait and turning performance, balance and falls. For intensity of exercise intervention, the training duration ranged from 3 weeks to 6 months, with 6 of the 13 papers using 12 weeks, with a time for each session ranging from $60-120$ minutes, with 8 of 13 papers providing a 60 -minute intervention session.

\subsection{Type of exercise of the reviewed articles}

The type of exercise can be categorized into 3 groups; 1) functional or specific exercise programme on turning and falling (e.g. Nordic walking, treadmill training, breathing exercises and others), 2) Tai Chi and 3) dance therapy (1 paper for Sardinian folk dance, 1 paper for ballroom and Latin American dance, 1 paper for Tango dance).

\subsubsection{Exercise category 1: The effects of functional or specific exercise programme on gait, turning and falling $(n=5)$}

In this category, there were 5 papers where authors studied the benefit of specific exercise programs to enhance trunk rotation using; relaxation techniques, flexibility exercises, gait and turning training. Exercise programs composed of various techniques and training which were practiced either in groups or individually with therapists. Fisher et al. $(2013)^{43}$ investigated the effects of treadmill training on striatal dopamine binding potential, motor symptoms and turning performance in 2 individuals with early stage of PD (within 1 year of diagnosis with PD) when compared to a no exercise group. The progressive treadmill training was provided by a physical therapist for 24 sessions over 8 weeks (60 minutes per session, 3 sessions per week). The training showed an increased striatal dopamine binding potential (BP) as well as improved turning performance. The participants' $\left[{ }^{18} \mathrm{~F}\right]$ fallypride $\mathrm{BP}$ was increased after treadmill training when compare to pre-exercise (pre-exercise average BP for participant 1 and $2=5.58 \pm 0.43$ and $7.14 \pm 0.36$, post-exercise average BP for participant 1 and $2=11.0 \pm 1.09$ and $12.9 \pm 0.47$ ), however no 
change in BP was seen in the participants who did not exercise. Similar to BP, the postural control score for turning task was increased only after the treadmill training (pre-exercise average postural control score for participant 1 and $2=0.25 \pm 0.03$ and $0.34 \pm 0.02$, postexercise average postural control score for participant 1 and $2=0.41 \pm 0.01$ and $0.52 \pm 0.05)$.

Park $^{37}$ (2014) compared the effects of individual and group communal exercise programs on gait performance and falls in a control group in individuals with mild to moderate IPD. The communal exercises were performed individually or in groups using a home-based smart application named "Parkinson home exercise application", which has been developed by the Association of Physiotherapists in Parkinson's Disease Europe (APPDE, 2009). This consisted of deep breathing exercises, relaxation techniques, and flexibility exercises including; trunk rotation, strengthening exercises, balance training and gait training. Participants followed the exercise program for 30 sessions over 10 weeks (60 minutes per session and three times per week). The results demonstrated that both group and individual communal exercises had a beneficial effect on improving gait capability by increasing velocity and cadence $(p<0.001)$. Moreover, group communal exercises also reduced fear of falling and increased fall efficacy post-training $(p<0.001)$. Stozek et al (2016) ${ }^{36}$ investigated the effects of a rehabilitation program using external sensory cues on turning, gait and motor performances in individuals with mild to moderate PD, when compared with a control group. The training program consisted of 28 sessions focusing on relaxation techniques, breathing exercises, range of motion and stretching exercises, exercises of trunk rotation in various positions, mobility exercises, balance training, gait training, simple dance, speech therapy and facial exercises over a 4week period. The findings indicated advantages of this program for balance, gait outcomes, physical performance and trunk rotation after training after a 1 month follow up and showed differences between groups at each testing time point $(\mathrm{p}<0.01)$.

Hubble et al. (2019) ${ }^{42}$ examined the effects of a trunk-specific exercise program on balance, freezing of gait, motor symptoms and quality of life in individuals with mildto-moderate IPD, when compared to a control group. The 12 session program consisted of exercises to improve range of motion, stability and endurance of trunk muscles including multifidus, erector spinae, obliques, transverse abdominus, rectus abdominus through 90 minute sessions which were delivered once a week. The results showed that participants in the exercise group had a decreased sway area $(p=0.029$ and 0.013 at 12 and 24 weeks), respectively; and decreased variability in mediolateral movement after training $(\mathrm{p}=0.042$ and 0.043 at 12 and 24 weeks), respectively.

Wróblewska et al. (2019) ${ }^{33}$ compared the effects of Nordic walking on balance, freezing of gait and gait parameters in individuals with mild to moderate PD compared to a no-intervention group. Participants were trained in outdoor Nordic walking for 24 sessions over 12 weeks. Nordic walking is walking with poles similar to skiing which requires the coordination between arms, core and legs. Participants who were in the Nordic walking group showed a reduction in their freezing of gait scores, improve Timed Up and Go and -e Provocative Test for Freezing and Motor Blocks after the end of the exercise program and after a 3 month follow up $(\mathrm{p}<0.01)$.

\subsubsection{Exercise category 2: effect of Tai chi exercise on gait, turning and falling $(n=4)$}

An exercise program which claimed to interact between cognitive and mobility consisted of Yoga Qi Gong and Tai Chi. Four papers considered the effects of Tai Chi 
exercise programs that included slow continuous, and circular movements in a flowing form that could facilitate large movement of trunk rotation.

Amano et al. $(2013)^{36}$ chose eight movements of the Yang-style. ${ }^{36}$ This style of Tai Chi facilitated a large range of movement of the neck, trunk and limbs combined with relaxation techniques such as breathing control. The authors compared effects of Tai Chi exercise on postural control, gait abilities and motor symptoms compared to a placebo group. Fifteen participants in an on-state of medication received Tai Chi exercises for 48 sessions (60 minutes for each session) over 16 weeks in a small group. The variables regarding postural control were focused on magnitude of displacement and velocity of gait initiation. The variables for gait performance were cadence, gait velocity, step length, step duration, percentage of swing time, percentage of double limb support time and gait asymmetry. They also measured symptoms of the disease by using the motor score in part III of Unified Parkinson's Disease Rating Scale (UPDRS). Amano et al. found no improvements after a 16-week program in any outcomes when considering the absolute change scores between pre- and post-intervention between the groups $(p=0.06-0.89)$. Nocera et al. $(2013)^{39}$ conducted a pilot study with the aim to investigate the effects of Tai Chi exercise on non-motor symptoms, balance and quality of life in 15 individuals with mild to moderate idiopathic PD (IPD) in an on-state of medication, which were compared with another 6 participants in a control group. The exercise intervention was over 48 sessions, with 60 minutes for each session, and 3 sessions each week over 16 weeks. The type of exercise was adapted from the first eight motions of the Yang-style short form, which focus on dynamic postural control during maximal movements. While participants in control group were asked to maintained their regular medication and did not received any exercise throughout 16 weeks. They measured the main outcome measure and also the quality of life using the Parkinson Disease Questionnaire 39 (PDQ39) and balance confidence using the Falls Efficacy Scale (FES). The results demonstrated that quality of life was improved after training $(p=0.04)$ as was the emotional well-being sub score $(\mathrm{p}=0.04)$.

Gao et al. (2014) $)^{38}$ compared the effects of Thai Chi on balance and functional mobility with no intervention group. They also gave Yang-style for Tai Chi exercise as in previous studies. Thirty-seven participants with IPD in an on-state of medication received Tai Chi for 36 sessions, 60 minutes for each session, with 3 sessions each week over 12 weeks. The outcomes used were the Berg Balance Scale (BBS), UPDRS part III, Timed Up \& Go (TUG) and occurrences of falls. The changed score after training of BBS was greater in the Tai Chi group $(p=0.002)$. Moreover, the occurrences of falls were decreased at the 6-month follow-up in the Tai Chi group for both the number of falls and average times of falls $(p=0.014$ and 0.032$)$, respectively. The results showed that a Tai Chi program appears to improve balance and reduces fall occurrences during the 6-month follow-up.

Vergara-Diaz et al. (2018) ${ }^{40}$ assessed the feasibility of a PD specific Tai Chi exercise program and its effects on; gait performance, motor symptoms, quality of life, executive function, balance and balance confidence when compare to usual care group. The exercise program consisted of 48 classes and face to face interaction. Participants attended 2 classes per week on average over a 6-month period and were instructed to practice by themselves outside of class for at least 60 minutes per week. The Tai Chi program composed of 6 Tai Chi movements, Tai Chi warm-up and cool-down exercises. The outcomes included gait parameters and clinical outcomes including; UPDRS, PDO39, Trial Making Test, Activity Specific Balance Confidence Scale (ABC), and TUG. Participants were all assessed in the off-state of medication. Gait abilities were 
investigated when performing dual-task such as reporting an object's location or number subtraction. The findings demonstrated a low number lost to follow-up, with approximately $70 \%$ of participants attending all Tai Chi classes. However, they only found non-significant improvements in some of the gait parameters in the Tai Chai group (p 0.07$)$.

In summary, 2 of the 4 papers conducted studies with similar intensity; 48 sessions over 16 weeks and similar 8 movement of the Yang-style short forms. However, these 2 studies did not find any improvement in motor symptoms, balance and gait performance. In contrast, the study which used the 24-form of the Yang-style short forms for 12 weeks demonstrated improvements in balance and a minimized number of fall events. While another study considered the feasibility of a training program using 6 Tai Chi movements over 6 months, although they reported some improvements of changing in gait parameters.

\subsubsection{Exercise category 3: effect of dance therapies on gait, turning and falling $(n=3)$}

Three papers examined the effects of dancing on motor performance, balance, and functional ability including gait and turning. The dance classes considered in this review were tango, Sardinian folk dance, ballroom and Latin American dance.

Rios et al. $(2015)^{41}$ aimed to compare the effects of Argentine tango on motor and nonmotor symptoms with a control group of self-directed exercise in mild to moderate IPD. The traditional Argentine tango classes were carried out through 24 partnered classes over 12 weeks, each class lasting 60 minutes with 2 classes each week. They measured motor symptoms using the UPDRS, balance using the Mini-Balance Evaluation Systems Test (Mini-BESTest), TUG and Dual-task TUG, fall questionnaire using Canadian Community Health Survey (CCHS), quality of life using PDQ-39, gait performance using Freezing of Gait Questionnaire (FOG-Q) and Krupp Fatigue Severity Scale, and nonmotor function using Purdue Pegboard, Montreal Cognitive Assessment (MoCA), Beck Depression Inventory (BDI) and Apathy Scale (AS). The findings showed that tango dance could improve functional mobility and balance $(p=0.032,0.042$ and 0.012$)$ for the Mini-BESTest, TUG and Dual-task TUG, respectively. Moreover, participants reported that they enjoyed the program.

Hulbert et al. (2017) ${ }^{13}$ compared the effects of ballroom and Latin American dance classes on turning capabilities with usual care control group in mild to moderate PD. The dancing program consisted of 20 partnered classes over 10 weeks, each class lasting 60 minutes with 2 classes each week. This paper described the details of the exercise program which included the head and trunk rotation with repetitive turning. The outcomes in this study were related to turning performance such as latency, time, angular change, number of turning steps, type and quality of turn. Surprisingly, the participants in the dance group demonstrated reduction in pelvic rotation $(-22.7 \%$ to $-11.6 \%)$ and an increase in the number of turning steps (13.8\%).

Solla et al. (2019) ${ }^{35}$ conducted a pilot study to investigate the effects of Sardinian folk dance (Ballu Sardu, BS) on motor symptoms, balance, gait ability and non-motor manifestations in individuals with mild to moderate PD when compared to a usual care control group. Sardinian folk dance was performed for 24 classes over 12 weeks, each class lasting 90 minutes with 2 classes per week. This type of dancing required the dancer to hold their hands or arms to form a circle and then rotate in a clockwise direction during stepping or small jumps. Thus, trunk rotation was performed repetitively during dancing. The findings indicated a decrease in motor symptoms, improving balance and gait 
performance $(\mathrm{p}<0.05)$. Moreover, non-motor symptoms including apathy and depression score were reduced after training $(\mathrm{p}<0.02)$. Among these 3 studies, the dance classes were conducted over $10-12$ weeks for repetitive trunk movement in all directions including rotation. All participants performed the training during the on-state of their regular medication, and the program showed improvements in balance, gait and trunk rotation.

\section{Discussion}

To our knowledge, this is the first scoping review of the effectiveness of exercisebased rehabilitation to improve gait and turning deficits which are relevant to falls in individuals with PD. Only 12 articles were included in this scoping review. In addition, the articles from a small number of randomised and non-randomised controlled trials have been retrieved, and they suggest that a specific exercise programme, Tai Chi and dance therapy can achieve improving in gait, turning and reducing the likelihood of falls in individuals with PD.

Most studies involved participants with mild to moderate PD, and only one study involved participants with severe PD. Gait, turning deficits and falls are common problems in individuals with PD who have impaired balance, therefore, including these types of participants can help determine the effectiveness of exercise on this population. In addition, the use of such exercise-based programmes to improve gait, turning and falling in individuals with PD can be placed into three categories: functional or specific exercise programmes, Tai Chi and dance therapy.

\subsection{Exercise category 1: functional or specific exercise programme on gait, turning and falling}

Locomotion performance including turning and gait disorders can be affected by impaired balance and postural instability, flexibility, strength, trunk stability and mobility, segment coordination and freezing. The functional and specific exercises can improve performance and lead to reduced fear of falling.

The study by Wroblewska et al. (2019) investigated Nordic walking (NW) on freezing of gait, TUG, and also using the total results of the Provocative Test for Freezing and Motor Blocks (PTFMB). ${ }^{33}$ The beneficial impact of NW on several gait parameters and falls in PD is well documented. ${ }^{44,45}$ It was suggested that NW can improve gait in PD because it is a form of external cueing that increases the rhythmicity of movements. ${ }^{45}$ In PD pathology, the impaired function of basal ganglia in PD leads to abnormalities of motor set and motor cues, and the consequences are initiation deficits and reduced step length. Such mechanisms may be responsible for incidents of gait blocking. ${ }^{46}$ Therefore, NW can be regarded as a form of cueing in which upper limb movements are the source of external information enabling the normalisation of speed and amplitude of the leg movements while walking. ${ }^{45}$

In addition, Park (2014) demonstrated a communal exercise program which focused on improving deep breathing, relaxation levels, flexibility, strength, balance and gait pattern using a smart application, resulting in improvements in gait parameters and fear of falling. ${ }^{37}$ The author suggested that external visual and auditory signs from a communal exercise program improved the spatiotemporal parameters of gait. In addition, a communal exercise enhanced emotional reactions, social interactions and physical ability. ${ }^{47}$ Therefore, these findings indicate that the communal exercise program, with visual and auditory feedback using a smart application, was beneficial for gait ability, fear of falling and fall efficacy. 
Hubble et al. (2019) examined the effects of a trunk-specific exercise-based intervention on balance in individuals with PD. ${ }^{42}$ The results showed that this type of exercise improved quiet-standing balance. A possible explanation for this finding could be the relative importance of the trunk muscles that are used to produce the corrective movements involved in maintaining an upright posture. ${ }^{34,48,49}$

The study by Stozek et al. (2016) ${ }^{34}$ found that a rehabilitation programme, focusing on mobility, balance and gait can improve motor function in terms of balance and other gait parameters. It can also improve the range of trunk rotation in individuals with PD, although this study did not provide any explanation of the mechanisms of this programme. However, analysis of the previous study ${ }^{50,51}$ indicates that this specific training focuses on problems that individuals with PD face when learning movements repetitively, individuals with $\mathrm{PD}$ can memorise their movements and, hence, eradicate these problems.

Finally, Fisher et al. $(2013)^{43}$ reported that a treadmill exercise program can improve Dopamine receptor D2 (DA-D2R) binding potential (BP) as a marker for receptor expression and as a turning performance marker in individuals with $\mathrm{PD}$. This exercise-induced improvement in postural control may be explained through a potential compensatory effect of the DA-D2R within the basal ganglia; this may also involve other related motor circuitry such as the cerebellum or the cerebral cortex. ${ }^{43}$

Taken together, functional or specific exercise has been proven to be beneficial for individuals with PD in terms of mobility, posture, upper limb function, strengthening, balance, gait and functional performance. This can be achieved by a range, type and duration of exercise to optimise the patient's independence, safety and well-being, thereby decreasing the risk of falling and enhancing quality of life. Exercise and motor training have also been used to improve balance, since balance impairments lead to high morbidity in PD. ${ }^{52}$ Some exercise modalities targeting both gait and balance also incorporate aspects of goal skill training while increasing cognitive engagement. ${ }^{52}$ For example, in amplitude training individuals with PD are asked to focus on generating large amplitude movements involving the whole-body during the practice of a skill. This form of exercise, which incorporates a significant amount of verbal feedback and attention strategy, results in improvements in movement speed as well as amplitude that appear to be analogous to results observed with a treadmill. ${ }^{33,34,37,42,43}$

\subsection{Exercise category 2: Tai Chi exercise on gait, turning and falling}

Tai Chi has been documented to have a beneficial effect on balance, mobility, gait and turning in PD, and it is also effective in reducing the incidence of falls. ${ }^{53-55}$ The included articles were used in the Tai Chi interventions and consisted of the first eight movements of the Yang-style ${ }^{54}$ short forms, which focus on dynamic postural control via weight shifting to control the centre of gravity during maximal movements. ${ }^{53}$ Findings from these studies show that following 24 weeks of twice weekly sessions, Tai Chi leads to improved gait and turning parameters as well as reduced falls. It is acknowledged that Tai Chi can improve postural equilibrium, which needs proprioceptive acuity and precise neuromuscular control. Furthermore, in the Tai Chi exercise, the slow multiple directional movements and concentration could increase proprioception, the strength of the lower limbs and attentiveness, as well as stability during weight shifting. ${ }^{36,39,53-55}$

Moreover, three of the four studies measured specific areas of cognitive executive function. ${ }^{36,38,39}$ The findings indicate that Tai Chi may not be an ideal mode to improve cognitive executive function combined with locomotion performance in individuals with 
PD. This is consistent with the findings from Lam et al. $(2014)^{56}$, in which patients at risk of progressive cognitive decline improved in attention span following a Tai Chi intervention. Therefore, the observation that performing a cognitive task while walking or turning disrupts locomotor control, suggesting that these tasks compete for shared resources involving specific neural networks. In elderly with and without PD, the cognitive task costs on locomotor control, and may arise in part from a reduction in cortical resources, faulty allocation of resources or slowing of the speed at which information is processed. ${ }^{54,55}$ Future studies that combine clinical gait assessments with targeted neuroimaging-based brain activation patterns and resting state neural network connectivity would significantly contribute to evaluating the neural basis underlying the impact of Tai Chi on cognitive-motor interactions in individuals with PD.

\subsection{Exercise category 3: dance therapy on gait, turning and falling}

Previous research has shown that the use of dance therapy is associated with improved motor function and balance capacity in individuals with PD, particularly Argentine tango and Irish set dancing. ${ }^{57,58}$ These studies focused on motor performance, appraising the effects of dance-based activities on gait, turning and falling, and three of the four studies also investigated affective or cognitive function.

The beneficial effects of dance compared to traditional exercise for balance and functional mobility has been suggested in studies on elderly participants and individuals with PD. ${ }^{13,35,41}$ Dance therapy requires specific motor skills, including repeated initiation and cessation, a diversity of movement speeds, rhythmic variation and spontaneous multidirectional perturbations. ${ }^{13,35,41}$ This type of exercise may be particularly beneficial for addressing backward walking, a crucial consideration given that many falls in PD are backwards. Furthermore, dance therapy requires working memory, attention and multitasking in order to integrate newly learned and previously-learned dance elements, staying in rhythm with the music and manoeuvring around others on the dance floor, all of which can be beneficial for cognition. ${ }^{13,35,41,57}$ Earhart and colleagues in 2009 showed that by the end of 12 months of tango dancing, individuals with PD had improved balance, walking and dual tasking capability. ${ }^{57}$ Finally, participants found the dance classes highly enjoyable and expressed overall satisfaction with the study, teachers and care. The social interaction, social support and social influences that emerged from the tango classes also have positive effects. Participation of spouses and friends in classes may have helped participants to feel more comfortable to challenge themselves in more complex and difficult movements, and provide a positive bonding activity for couples often dealing with negative consequences of the disease. It is unclear how dance may specifically maintain the co-ordination between body segments, however, the principles of motor relearning indicate that cortico-motor neuron pools are organised relative to specific tasks, with increasing evidence of neuro-plastic changes associated with training in functional tasks rather than specific impairments ${ }^{13}$. This provides the potential for motor training eliciting neuro-plastic changes, and re-organisation in the pathological brain such as synaptogenesis, axonal sprouting, reorganisation of 'motor control maps' in the homunculus and up-or down-regulation of neuro transmitters to improve motor output. ${ }^{13}$, 41,57 In addition to the internal adaptations from dance, the multidimensional external influence of visual cues from the teacher, auditory cues from the music and tactile cues from the partner are also likely to have had a positive influence, leading to their support for recommended use in the recent European physiotherapy guidelines for PD. ${ }^{27,29}$ 


\section{Conclusions}

Problems with gait, turning deficits and frequency of falls can affect individuals with PD. Functional or specific exercise programmes relevant to locomotion performance, Tai Chi and dance therapy have been shown to improve temporal, spatial and kinematic parameters in gait and turns and can lead to improvements in parameters associated with falls. Such interventions should be considered as vital components of treatment which should be an integral part of the implementation process of rehabilitation in functional performance. However further work needs to be conducted to determine which specific exercise interventions are most beneficial for individuals with PD.

\section{Conflict of Interest}

The authors have no conflict of interest. 
Supplementary material - The logical structure search for each database.

Table 1. Description of included article

\begin{tabular}{|c|c|c|c|}
\hline Author (year) & Study location & Population Studied & Interventions \\
\hline $\begin{array}{l}\text { Amano et al. } \\
\text { (2013) }\end{array}$ & $\begin{array}{l}\text { Project 2: University of } \\
\text { Florida in Gainesville, FL, } \\
\text { USA }\end{array}$ & $\begin{array}{l}\text { - } 30 \text { participants: exercise }=15, \text { control }=15 \\
\text { - Male:female, exercise }=7 / 8, \text { control }=7 / 2 \\
\text { - Mean age: exercise }=66 \text { years, control }=66 \text { years } \\
\text { - Hoehn and Yahr stage }=2.4 \text { for both groups }\end{array}$ & $\begin{array}{l}\text { Tai Chi interventions included of the eight movements of } \\
\text { the Yang-style short forms which is emphasized components of } \\
\text { movement typically limited in PD. } \\
\text { - } \quad \text { Duration of exercise: } 3 \text { weeks, } 60 \text { mins/session }\end{array}$ \\
\hline $\begin{array}{l}\text { Nocera et al. } \\
(2013)\end{array}$ & $\begin{array}{l}\text { the Applied Neuromechanics } \\
\text { laboratory, VA } \\
\text { Rehabilitation Center of } \\
\text { Excellence, Atlanta VACM, } \\
\text { Decatur, GA, USA }\end{array}$ & $\begin{array}{l}\text { - } 21 \text { participants: exercise }=15, \text { control }=6 \\
\text { - Male:female, exercise }=7 / 8, \text { control }=4 / 2 \\
\text { - Mean age: exercise }=66 \text { years, control }=65 \text { years } \\
\text { - Hoehn and Yahr stage }=2-3 \text { for both groups }\end{array}$ & $\begin{array}{l}\text { - Each Tai Chi session began with a typical warm-up } \\
\text { focused on kinesthetic awareness of the body in space, relaxed } \\
\text { breathing and mental relaxation. Then, traditional movements were } \\
\text { incorporated using the first eight motions of the Yang style short } \\
\text { form } \\
\text { - Duration of exercise: } 16 \text { weeks, } 60 \mathrm{mins} / \mathrm{session}\end{array}$ \\
\hline $\begin{array}{l}\text { Fisher et al. } \\
(2013)\end{array}$ & $\begin{array}{l}\text { Department of Neurology, } \\
\text { University of Southern } \\
\text { California, Los Angeles, } \\
\text { USA }\end{array}$ & $\begin{array}{l}\text { - } 4 \text { participants: exercise }=2 \text {, control }=2 \\
\text { - Male:female, No specific } \\
\text { - Mean age: No specific } \\
\text { - Hoehn and Yahr stage }=\text { early stage for both groups }\end{array}$ & $\begin{array}{l}\text { - Treadmill training at progressively increasing } \\
\text { Speeds. Participants were challenged to walk and/or } \\
\text { run faster than their self-selected speed but within the } \\
\text { constraints of an observationally normal gait pattern. - } \\
\text { Duration of exercise: } 8 \text { weeks, } 60 \text { mins/session }\end{array}$ \\
\hline $\begin{array}{l}\text { Gao et al. } \\
(2013)\end{array}$ & $\begin{array}{l}\text { the West China Hospital in } \\
\text { Sichuan, China }\end{array}$ & $\begin{array}{ll}- & 76 \text { participants: exercise }=37, \text { control }=39 \\
- & \text { Male:female, exercise }=23 / 14, \text { control }=27 / 12 \\
- & \text { Mean age: } \text { exercise }=69 \text { years, control }=68 \\
\text { years } & \\
\text { - } & \text { Hoehn and Yahr stage: } \text { mild } / \text { moderate } / \text { severe } \\
\text { exercise }=1 / 19 / 17, \text { control }=6 / 12 / 21\end{array}$ & $\begin{array}{l}\text { The Tai Chi classes were given by an experienced Tai Chi } \\
\text { instructor who was good at } 24 \text {-form Yang Style Tai Chi. This kind } \\
\text { of Tai Chi is easy to learn and is the most popular Tai Chi in } \\
\text { China. It emphasizes diagonal weight shifting, awareness of body } \\
\text { position and breathing. } \\
\text { - Duration of exercise: } 12 \text { weeks, } 60 \text { mins/session }\end{array}$ \\
\hline
\end{tabular}




\begin{tabular}{|c|c|c|c|}
\hline Park (2014) & $\begin{array}{l}\text { College of Sports and } \\
\text { Leisure, Korea University, } \\
\text { Sejong, Korea }\end{array}$ & $\begin{array}{l}-\quad 30 \text { participants: exercise group }=10, \text { individual } \\
\text { exercise }=10, \text { control }=9 \\
-\quad \text { Male:female, exercise group }=1 / 9, \text { individual } \\
\text { exercise } \\
=1 / 9, \text { control }=1 / 8 \\
-\quad \text { Mean age: exercise group }=71 \text { years, individual } \\
\text { exercise }=73, \text { control }=72 \text { years } \\
-\quad \text { Hoehn and Yahr stage, exercise group }=2.7, \\
\text { individual exercise }=2.4, \text { control }=2.5\end{array}$ & $\begin{array}{l}\text { Subjects performed a communal exercise program using a } \\
\text { smart application which focused on improving their deep } \\
\text { breathing, relaxation levels, flexibility, strength, balance, and gait } \\
\text { pattern } \\
\text { - } \quad \text { Duration of exercise: } 10 \text { weeks, } 60 \text { mins/session }\end{array}$ \\
\hline $\begin{array}{l}\text { Rios Romenets } \\
\text { et al. (2015) }\end{array}$ & $\begin{array}{l}\text { McGill University health } \\
\text { center, Canada }\end{array}$ & $\begin{array}{l}\text { - } 33 \text { participants: exercise }=18, \text { control }=15 \\
\text { - Male:female, exercise }=12 / 6, \text { control }=7 / 8 \\
\text { - Mean age: exercise }=63.2 \text { years, control }=64.3 \text { years } \\
\text { - Hoehn and Yahr stage }=\text { I - III }\end{array}$ & $\begin{array}{l}\text { - Traditional Argentine tango classes controlled by two tango } \\
\text { instructors with usual physical activities and exercise program - } \\
\text { Duration of exercise: } 2 \text { session/week, } 12 \text { weeks }\end{array}$ \\
\hline $\begin{array}{l}\text { Stozek et al. } \\
\text { (2016) }\end{array}$ & $\begin{array}{l}\text { Movement Disorders Clinic, } \\
\text { Department of Neurology, } \\
\text { University Hospital in } \\
\text { Cracow, Poland }\end{array}$ & $\begin{array}{l}\text { - } 61 \text { participants: exercise }=30, \text { control }=31 \\
\text { - Male:female, exercise }=13 / 17, \text { control }=16 / 15 \\
\text { - Mean age: exercise }=64 \text { years, control }=67 \text { years } \\
\text { - Hoehn and Yahr stage }=2.3 \text { for both groups } \\
\text { - UPDRS-III score: exercise }=19.7, \text { control }=23.2\end{array}$ & 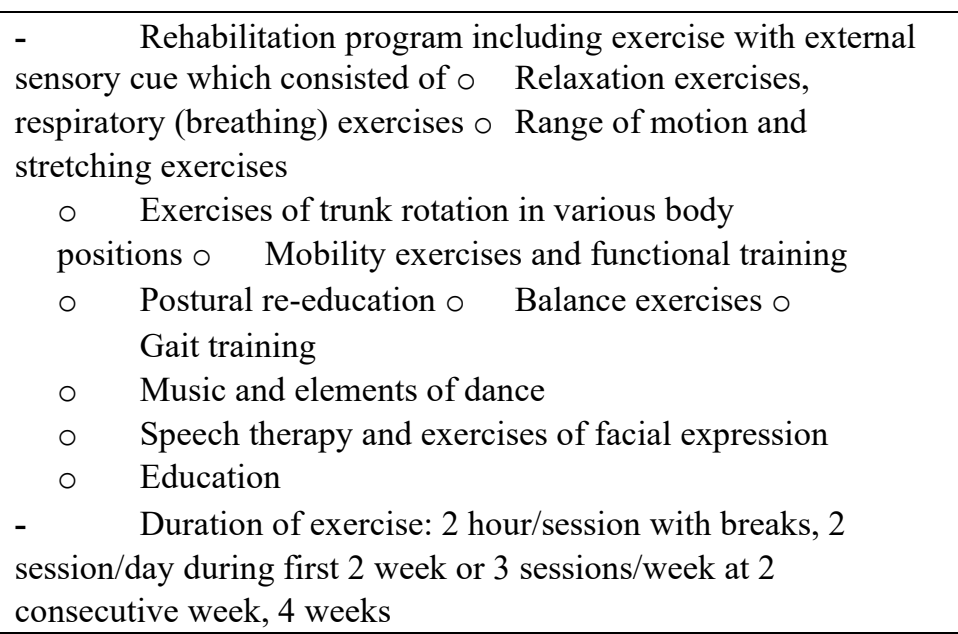 \\
\hline $\begin{array}{l}\text { Hulbert et al. } \\
\text { (2017) }\end{array}$ & $\begin{array}{l}\text { National Institute for Health } \\
\text { Research, Research for } \\
\text { Patient Benefit, } \\
\text { Southampton, United } \\
\text { Kingdom }\end{array}$ & $\begin{array}{l}\text { - } 24 \text { participants: exercise }=12, \text { control }=12 \\
\text { - Male:female, exercise }=7 / 5, \text { control }=5 / 7 \\
\text { - Mean age: } \text { exercise }=73.4 \text { years, control }=71.7 \text { years } \\
\text { - Hoehn and Yahr stage: exercise }=1.8, \text { control }=1.9\end{array}$ & $\begin{array}{l}\text { - Dance intervention alongside usual care taught by two } \\
\text { experienced ballroom and Latin American teachers and supported } \\
\text { by a physical therapist } \\
\text { - } \quad \text { Duration of exercise: } 1 \text { hour/session, } 2 \text { sessions/week, } 10 \\
\text { weeks }\end{array}$ \\
\hline
\end{tabular}




\begin{tabular}{|c|c|c|c|}
\hline $\begin{array}{l}\text { Vergara-Diaz } \\
\text { et al. (2018) }\end{array}$ & $\begin{array}{l}\text { Boston area neurology } \\
\text { practice and PD support } \\
\text { groups (Brigham and } \\
\text { Women's hospital and } \\
\text { Boston Medical Center), } \\
\text { Massachusetts, USA }\end{array}$ & $\begin{array}{ll}- & 32 \text { participants: exercise }=16, \text { control }=16 \\
- & \text { Male:female, exercise }=9 / 7, \text { control }=7 / 9 \\
- & \text { Mean age: exercise }=65.7 \text { years, control }=62 \\
\text { years } & \\
- & \text { Hoehn and Yahr stage: } 2 / 2.5 \text { exercise }=11 / 5, \\
\text { control }=13 / 3 \\
-\quad & \text { UPDRS-III score: } \text { exercise }=26.38, \text { control }= \\
20.63 & \end{array}$ & $\begin{array}{l}\text { 2-person interactive exercise with meditative music } \\
\text { - } \\
\text { of class } 60 \text { minute/week, } 6 \text { months }\end{array}$ \\
\hline $\begin{array}{l}\text { Hubble et al. } \\
\text { (2019) }\end{array}$ & $\begin{array}{l}\text { Metropolitan neurology } \\
\text { clinic, Australia }\end{array}$ & $\begin{array}{l}\text { - } 22 \text { participants: exercise }=11, \text { control }=11 \\
\text { - Male:female, exercise }=7 / 4, \text { control }=8 / 3 \\
\text { - Mean age: exercise }=63.3 \text { years, control }=67.5 \text { years } \\
\text { - Hoehn and Yahr stage: exercise }=1.8, \text { control }=2.0 \\
\text { - UPDRS-III score: exercise }=17.3, \text { control }=21.5\end{array}$ & $\begin{array}{l}\text { - Exercise (to improve trunk mobility and endurance) and fall } \\
\text { prevention education consisted of } \circ \text { Warmup focusing on } \\
\text { trunk mobility exercises to improve range of motion } \\
\circ \text { Exercise routine focusing on the endurance and stability of } \\
\text { the trunk muscles (multifidus, erector spinae, obliques, } \\
\text { transverse abdominus, rectus abdominus) } \\
\text { Cool down involving stretching and walking in a real-world } \\
\text { environment } \\
\text { - Duration of exercise: } 90 \text { minutes/session, } 1 \text { sessions/week, } 12 \\
\text { weeks }\end{array}$ \\
\hline $\begin{array}{l}\text { Wróblewska et } \\
\text { al. (2019) }\end{array}$ & $\begin{array}{l}\text { Department of } \\
\text { Extrapyramidal Diseases, } \\
\text { Medical University of Łódź, } \\
\text { Poland }\end{array}$ & $\begin{array}{ll}- & 40 \text { participants: exercise }=20, \text { control }=20 \\
- & \text { Male:female, exercise }=8 / 12, \text { control }=9 / 11 \\
- & \text { Mean age: exercise }=72 \text { years, control }=67 \\
\text { years } & \\
- & \text { Hoehn and Yahr stage, II-III: exercise II }=9 \text { and } \\
\text { III }=11, \text { control II }=11 \text { and III }=9\end{array}$ & $\begin{array}{l}\text { - Nordic Walking to improve gait in PD. } \\
\text { - Duration of exercise: } 12 \text { weeks, } 60 \text { mins/session }\end{array}$ \\
\hline $\begin{array}{l}\text { Solla et al. } \\
\text { (2019) }\end{array}$ & $\begin{array}{l}\text { Movement Disorders Clinic } \\
\text { of the University of Cagliari, } \\
\text { Cagliari, Italy }\end{array}$ & $\begin{array}{l}\text { - } 20 \text { participants: exercise }=10, \text { control }=10 \\
\text { - Male:female, exercise }=6 / 10, \text { control }=7 / 10 \\
\text { - Mean age: exercise }=67.8 \text { years, control }=67.1 \text { years } \\
\text { - Hoehn and Yahr stage: exercise }=2.1, \text { control }=2.3 \\
\text { - UPDRS-III score: exercise }=26.38, \text { control }=20.63\end{array}$ & $\begin{array}{ll}- & \text { Sardinian folk dance (Ballu Sardu, BS) } \\
- & \text { Duration of exercise: } 24 \text { classes, } 90 \text { minutes/class } \\
\text { sessions, } 2 \text { sessions/week, } 12 \text { weeks }\end{array}$ \\
\hline
\end{tabular}

\section{Abbreviation:}

PD - Parkinson's disease

UPDRS - Unified Parkinson's Disease Rating Scale Table 2. Articles addressing

intervention needs, outcome measures and main findings.

\begin{tabular}{|l|l|l|l|}
\hline Author (year) & Study objective & Outcome measures & Main findings \\
\hline
\end{tabular}




\begin{tabular}{|c|c|c|c|}
\hline $\begin{array}{l}\text { Amano et al. } \\
\text { (2013) }\end{array}$ & $\begin{array}{l}\text { To investigate the effect of Tai Chi } \\
\text { exercise on dynamic postural control } \\
\text { during gait initiation and gait } \\
\text { performance in individuals with } \\
\text { idiopathic PD }\end{array}$ & $\begin{array}{l}\text { 1. Gait Initiation - anticipatory postural adjustments } \\
\text { (APAs) function to initially move the center of pressure } \\
\text { (COP) backward and towards the swing limb prior to an } \\
\text { initial heel-off of the swing limb } \\
\text { 2. Gait - cadence, gait velocity, step length, step } \\
\text { duration, swing time (\% of gait cycle), double limb support } \\
\text { time (\% of gait cycle), and gait asymmetry } \\
3 \text {. Clinical outcomes - 14-item Part III of the } \\
\text { UPDRS }\end{array}$ & $\begin{array}{l}\text { The exercise group who received Tai Chi exercise } \\
\text { did not improve gait initiation or gait } \\
\text { performance or clinical outcomes in these cohorts } \\
\text { of persons with mild to moderate PD (i.e., range } \\
\text { of } 2 \text { to } 3 \text { of Hoehn and Yahr scale). }\end{array}$ \\
\hline $\begin{array}{l}\text { Nocera et al. } \\
\text { (2013) }\end{array}$ & $\begin{array}{l}\text { To determine the effects of Tai Chi } \\
\text { exercise on the non-motor } \\
\text { symptomology in Parkinson's disease. } \\
\text { The specific objectives were } \\
\text { (1) there is a positive effect of Tai Chi } \\
\text { on cognition in specific indices of } \\
\text { executive function. And (2) is quality } \\
\text { of life (QOL) as measured by the } \\
\text { Parkinson } \\
\text { Disease Questionnaire } 39 \text { (PDQ-39) } \\
\text { and balance confidence positively } \\
\text { impacted following } \\
\text { Tai Chi in persons with PD? }\end{array}$ & $\begin{array}{l}\text { - Digit Span Backward Subtest from } \\
\text { - Wechsler Memory Scale } \\
\text { - Letter Verbal Fluency } \\
\text { - Category Verbal Fluency } \\
\text { - Stroop Color Word Test } \\
\text { - Trails A and B } \\
\text { - Parkinson Disease Questionnaire } 39 \text { (PDQ-39) } \\
\text { - Tinetti's Falls Efficacy Scale }\end{array}$ & $\begin{array}{l}\text { - Tai Chi training group had significantly } \\
\text { better scores following the intervention than the } \\
\text { control group on the Parkinson's disease } \\
\text { Questionnaire-39 total score as well as the } \\
\text { emotional well-being sub score. Trends for } \\
\text { improvement were noted for the Tai Chi group } \\
\text { on Digits Backwards, Tinetti's Falls Efficacy } \\
\text { Scale, and the activities of daily } \\
\quad \text { This pilot study justify the potential for } \\
\text { - } \\
\text { a larger, randomized controlled trial to better } \\
\text { understand the impact of the non-motor } \\
\text { symptoms of PD there is a great need to identify } \\
\text { treatments that will have an impact from a } \\
\text { physical, cognitive and psychological } \\
\text { perspective. }\end{array}$ \\
\hline
\end{tabular}




\begin{tabular}{|c|c|c|c|}
\hline $\begin{array}{l}\text { Fisher et al. } \\
\text { (2013) }\end{array}$ & $\begin{array}{l}\text { To examine the effects of intensive } \\
\text { treadmill exercise on DA-D2R binding } \\
\text { potential using PET imaging with } \\
{[18 \mathrm{~F}] \text { fallypride in individuals with }} \\
\text { early-stage and unmedicated PD and to } \\
\text { measured exercise-induced changes in } \\
\text { motor performance, specifically } \\
\text { turning behavior in PD }\end{array}$ & $\begin{array}{l}\text { PET imaging and MRI - Kinematic } \\
\text { methods, postural } \\
\text { control during turning was quantified as the peak distance } \\
\text { between the COP } \\
\text { supporting foot and the extrapolated center of mass (COM) } \\
\text { - UPDRS scores }\end{array}$ & $\begin{array}{l}\text { - An exercise-induced increase in DA-D2R } \\
\text { expression in the basal ganglia of patients with } \\
\text { early-stage and unmedicated PD. This strengthens } \\
\text { the validity of translating findings from the } \\
\text { laboratory to meaningful clinical practice, } \\
\text { impacting patients' quality of life .In addition, } \\
\text { this study demonstrates feasibility for intensive } \\
\text { and challenging exercise in unmedicated and } \\
\text { early-stage PD patients and supports the need for } \\
\text { larger studies. }\end{array}$ \\
\hline $\begin{array}{l}\text { Gao et al. } \\
\text { (2013) }\end{array}$ & $\begin{array}{l}\text { - To examine the effects of Tai Chi on } \\
\text { balance and functional mobility in } \\
\text { individuals with } \\
\text { Parkinson's disease and to determine } \\
\text { whether fall incidence could be reduced } \\
\text { by the Tai Chi exercise. }\end{array}$ & $\begin{array}{l}\text { - UPDRS part III } \\
\text { - Berg Balance Scale (BBS) } \\
\text { - Time Up and Go (TUG) }\end{array}$ & $\begin{array}{l}\text { - Tai Chi training can improve BBS but not } \\
\text { improve in UPDRS part III scores and TUG. The } \\
\text { study findings suggested that Tai Chi exercise } \\
\text { could improve the balance and decrease the fall } \\
\text { risks in patients with Parkinson's disease. }\end{array}$ \\
\hline Park (2014) & $\begin{array}{l}\text { To investigate the effects of a regular } \\
\text { communal exercise program with a } \\
\text { smart application for visual and } \\
\text { auditory feedback in patients with PD } \\
\text { on gait ability, fear of falling, and fall } \\
\text { efficacy }\end{array}$ & $\begin{array}{l}\text { - Gait parameters (velocity and cadence) } \\
\text { - Fear of Falling Questionnaire } \\
\text { - The Korean Falls Efficacy Scale }\end{array}$ & $\begin{array}{l}\text { The communal exercise program, with visual and } \\
\text { auditory feedback of the smart application, was } \\
\text { beneficial for gait ability, fear of falling, and fall } \\
\text { efficacy. }\end{array}$ \\
\hline $\begin{array}{l}\text { Rios } \\
\text { Romenets et } \\
\text { al. (2015) }\end{array}$ & $\begin{array}{l}\text { To determine effects of Argentine tango } \\
\text { on motor and non-motor manifestations } \\
\text { of Parkinson's disease }\end{array}$ & $\begin{array}{l}\text { 1. Part III of the MDS-UPDRS } \\
\text { 2. Motor/Gait outcomes } \circ \text { Off fluctuations and } \\
\text { dyskinesia, from the MDS- } \\
\text { UPDRS } \\
\text { Mini-Balance Evaluation Systems Test (Mini- } \\
\text { BESTest-) of Dynamic Balance } \odot \text { Timed Up } \\
\text { and Go (TUG) and Dual-task TUG } \circ \quad \text { Falls } \\
\text { questionnaire (Canadian Community Health } \\
\text { Survey (CCHS) } \circ \text { Freezing of Gait } \\
\text { Questionnaire (FOG-Q) } \\
\circ \quad \text { Purdue Pegboard }\end{array}$ & $\begin{array}{l}\text { The exercise group who participated tango } \\
\text { classes improve functional mobility (measured by } \\
\text { examiner-rated clinical global impression), } \\
\text { balance (measured by Mini-BESTest simple TUG } \\
\text { time and TUG dual task score) of persons with } \\
\text { mild to moderate PD (i.e., range of } 1 \text { to } 3 \text { of } \\
\text { Hoehn and Yahr scale). Moreover, tango } \\
\text { participants fount the activity more enjoyable and } \\
\text { felt more overall treatment satisfaction. }\end{array}$ \\
\hline
\end{tabular}




\begin{tabular}{|c|c|c|c|c|}
\hline & & $\begin{array}{l}\text { O } \\
\text { Sev } \\
\text { Que } \\
\text { Imp } \\
\text { que } \\
\text { sati }\end{array}$ & 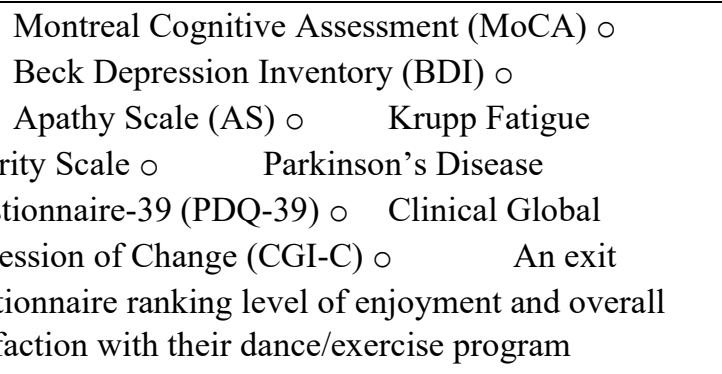 & \\
\hline $\begin{array}{l}\text { Stozek et al. } \\
(2016)\end{array}$ & $\begin{array}{l}\text { To assess the effects of the } \\
\text { rehabilitation program on balance, gait, } \\
\text { motor performance and trunk rotations } \\
\text { in PD patients. }\end{array}$ & $\begin{array}{l}- \\
- \\
- \\
\\
\\
\end{array}$ & $\begin{array}{l}\text { Pastor test (score) (shoulder tug) } \\
\text { Tandem stance time } \\
10 \mathrm{~m} \text { walk } \\
\text { Time } \\
\text { Number of steps } 0 \\
\text { tep } \\
360 \text { degree turn, number of steps } \\
\text { Physical performance test (PPT) score } \\
\text { Standing up from sitting position time } \\
\text { Standing up from lying position on treatment table } \\
\text { Standing up from lying position on mat time } \\
\text { Standing up from lying to sitting position time } \\
\text { Sitting down from standing position time } \\
\text { Lying down on treatment table, from standing } \\
\text { time } \\
\text { Lying down on treatment table from sitting } \\
\text { time } \\
\text { Lying down on mat from standing position time } \\
\text { Supine to side lying position on treatment table } \\
\text { Supine to prone lying position on exercise mat } \\
\text { Lumbar spine rotation (right and left) } \\
\text { Thoraco-lumbar spine rotation (right and left) }\end{array}$ & $\begin{array}{l}\text { - The PD participants in rehabilitation } \\
\text { group of significantly improved in balance and } \\
\text { gait outcomes, physical performance (when } \\
\text { measured by PPT score and timed activities) and } \\
\text { trunk rotation after complete rehabilitation } \\
\text { program when compare to baseline. } \\
\text { - The positive effects of exercise program } \\
\text { maintained for at least } 1 \text { month. }\end{array}$ \\
\hline
\end{tabular}




\begin{tabular}{|c|c|c|c|}
\hline $\begin{array}{l}\text { Hulbert et al. } \\
\text { (2017) }\end{array}$ & $\begin{array}{l}\text { - To investigate the effects of } \\
\text { ballroom and Latin American dancing } \\
\text { classes on turning in people with } \\
\text { Parkinson's. }\end{array}$ & 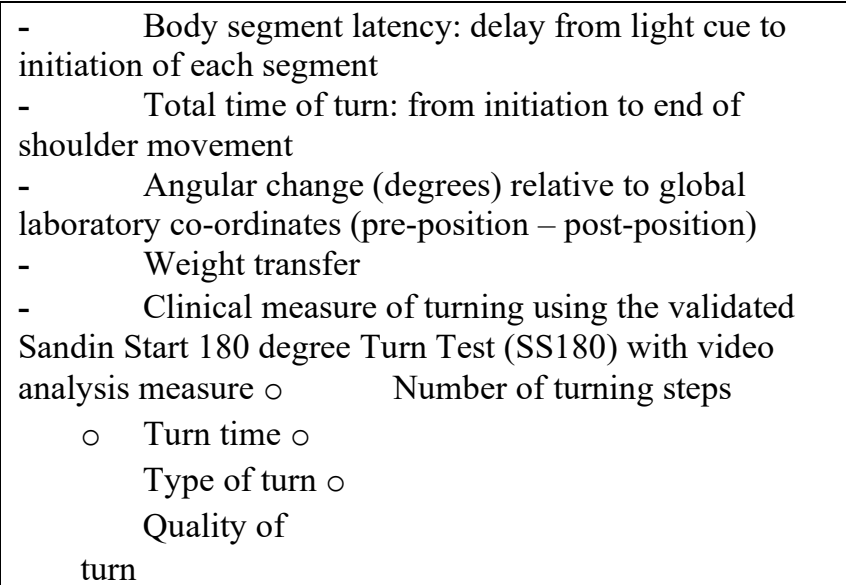 & $\begin{array}{l}\text { There was no change in body segment } \\
\text { latency in Dance group of mild to moderate PD } \\
\text { (range of } 1 \text { to } 3 \text { of Hoehn and Yahr scale). } \\
\text { - The dance group decreased the rotation } \\
\text { of pelvis and increased the number of steps to } \\
\text { turn over time. These findings indicate that } \\
\text { people with Parkinson's are affected by dancing. }\end{array}$ \\
\hline $\begin{array}{l}\text { Vergara-Diaz } \\
\text { et al. (2018) }\end{array}$ & $\begin{array}{l}\text { To assess the feasibility and inform } \\
\text { design features of a fully powered } \\
\text { randomized controlled trial (RCT) } \\
\text { evaluating the effects of Tai Chi (TC) } \\
\text { in Parkinson's disease (PD) and to } \\
\text { select outcomes most responsive to TC } \\
\text { assessed during off-medication states. }\end{array}$ & 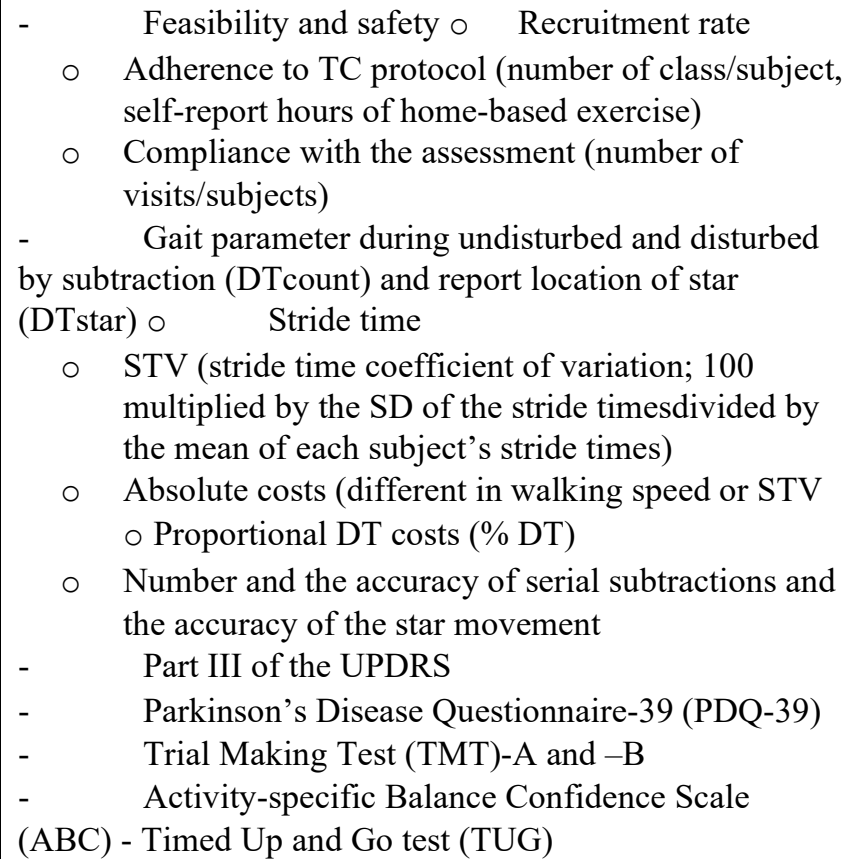 & $\begin{array}{l}-\quad \text { Recruitment rate }=0.08 \text { subjects/day } \\
-\quad \text { Loss of follow-up rate }=1.25 \% \\
-\quad \text { Attendance of } 48 \text { scheduled TC classes } \\
10-92 \% \\
(\text { estimated percentage }=70 \%) \\
-\quad \text { Tai Chi }(\mathrm{TC}) \text { group of mild to moderate } \\
\text { PD (range of } 1 \text { to } 2.5 \text { of Hoehn and Yahr scale) } \\
\text { were observed nonsignificant improvement of DT } \\
\text { gait } \\
\text { STV at } 6 \text { months } \\
-\quad \text { Absolute and percent DT cost of STV } \\
\text { showed trend to lower in TC }\end{array}$ \\
\hline
\end{tabular}




\begin{tabular}{|c|c|c|c|}
\hline $\begin{array}{l}\text { Hubble et al. } \\
\text { (2019) }\end{array}$ & $\begin{array}{l}\text { to examine the effects of a } 12 \text {-week } \\
\text { trunk-specific exercise-based } \\
\text { intervention on balance in people with } \\
\text { PD. }\end{array}$ & $\begin{array}{l}\text { - Center of pressure during 30-second standing balance } \\
\text { under conditions } \circ \quad \text { On a firm surface with eyes } \\
\text { open } \circ \quad \text { On a firm surface with eyes closed } ~ \\
\text { On a foam surface with eyes open } \circ \\
\text { foam surface with eyes closed } \circ \text { Measuring } \\
\text { - Sway area, velocity, variability of anteroposterior and } \\
\text { medio-lateral (ML) sway patterns } \\
\text { - Balance confidence (Activity-Specific Balance } \\
\text { Confidence Scale) } \\
\text { - Quality of life (39-item Parkinson Disease } \\
\text { Questionnaire) } \\
\text { - Freezing of gait (Freezing of Gait Questionnaire) } \\
\text { - Prescription medication use } \\
\text { - Timed Up and Go test } \\
\text { - Part III of the UPDRS } \\
\text { - Modified Hoehn and Yahr Scale } \\
\text { Schwab and England Activities of Daily Living Scale }\end{array}$ & $\begin{array}{l}\text { - Both groups of mild to moderate PD (range of } 1 \\
\text { to } 2.5 \text { of Hoehn and Yahr scale) exhibited } \\
\text { significantly increased sway area, sway velocity, } \\
\text { and sway variability when their eyes were closed } \\
\text { - Exercise group significantly reduced sway area } \\
\text { and ML sway variability at } 12 \text { and } 24 \text { weeks }\end{array}$ \\
\hline $\begin{array}{l}\text { Solla et al. } \\
\text { (2019) }\end{array}$ & $\begin{array}{l}\text { To evaluate the effects of } \\
\text { Sardinian folk dance (Ballu Sardu, BS) } \\
\text { on functional performance and motor } \\
\text { and nonmotor symptoms in individuals } \\
\text { with PD. }\end{array}$ & $\begin{array}{l}\text { - Part III of the UPDRS } \\
\text { - Six-minute walk test (6MWT) } \\
\text { - Berg Balance Score (BBS) } \\
\text { - Timed Up and Go test (TUG) } \\
\text { - Five time sit to stand test (FTSSTX } \\
\text { - Back Scratch Test (BST) } \\
\text { - Sit-and-Reach Test (SRT) } \\
\text { - Parkinson's Disease Fatigue Scale (PFS-16) } \\
\text { - Beck Depression Inventory } \\
\text { - Starkstein Apathy Scale (SAS) } \\
\text { - Montreal Cognitive Assessment (MOCA) scale } \\
\text { - Gait analysis with three magnetoinertial measurement } \\
\text { units (MIMUs) during } 2 \text { meter walk test } \\
\quad \quad \text { Stride length (m) } \\
\quad \quad \text { Gait speed (m/s) } \bigcirc\end{array}$ & $\begin{array}{l}\text { The Sardinian Folk Dance group of mild to } \\
\text { moderate PD (range of } 1 \text { to } 2.5 \text { of Hoehn and } \\
\text { Yahr scale) demonstrate the improvement of } \\
\text { motor symptoms (measured by UPDRS-III), } \\
\text { balance (measured by BBS, TUG), lower length } \\
\text { strength (measured by FTSST), flexibility } \\
\text { (measured by BST), gait performance and } \\
\text { nonmotor symptoms (measured by BDI and SAS) }\end{array}$ \\
\hline
\end{tabular}




\begin{tabular}{|c|c|c|c|}
\hline & & $\begin{array}{l}\text { Cadence } \\
\text { (steps } / \mathrm{min} \text { ) }\end{array}$ & \\
\hline & & $\begin{array}{l}\circ \text { Number of straight walks, and straight walking } \\
\text { time (s) } \\
\circ \text { Gait fatigue index (GFI) }\end{array}$ & \\
\hline $\begin{array}{l}\text { Wróblewska } \\
\text { et al. (2019) }\end{array}$ & $\begin{array}{l}\text { To assess the impact of Nordic } \\
\text { Walking training on freezing of gait in } \\
\text { PD. }\end{array}$ & $\begin{array}{ll}- & \text { Freezing of Gait Questionnaire (FOG) } \\
- & \text { Timed Up and Go test (TUG) } \\
- & \text { Provocative Test for Freezing and Motor Blocks } \\
\text { (PTFMB) }\end{array}$ & $\begin{array}{l}\text { NW training has a beneficial effect on FOG by } \\
\text { significantly reducing turning and step initiation } \\
\text { of FOG. }\end{array}$ \\
\hline
\end{tabular}

Abbreviation:

PD - Parkinson's disease

UPDRS - Unified Parkinson's Disease Rating Scale 
Figure 1. Study PRISMA flow diagram for the scoping process.

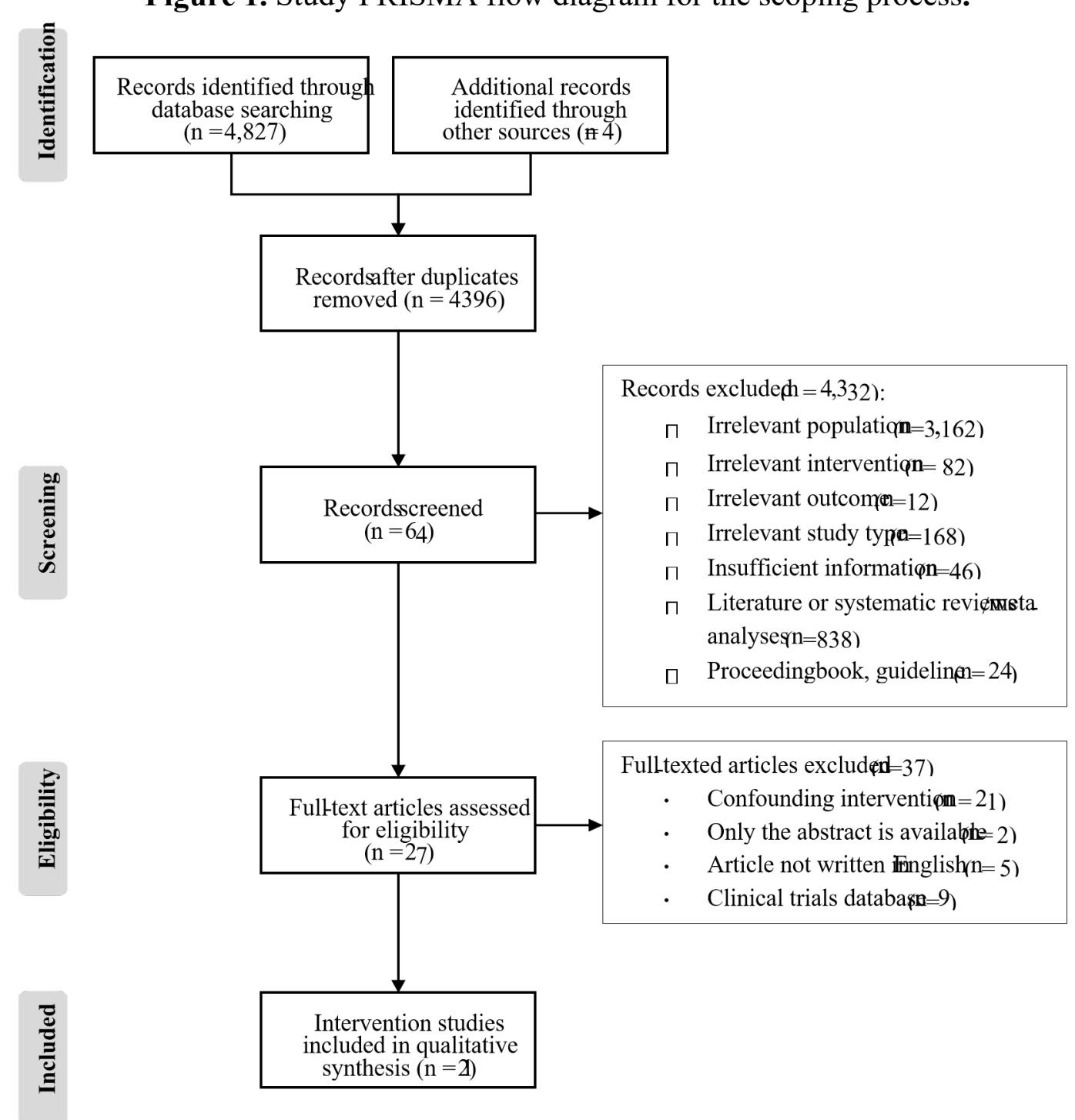


7. Reference 1. Mazzoni P, Shabbott B, Cortés JC. Motor control abnormalities in Parkinson's disease. Cold Spring Harb Perspect Med. 2012;2(6):1-17.

2. Raggi A, Leonardi M, Ajovalasit D, Carella F, Soliveri P, Albanese A, et al. Disability and profiles of functioning of patients with Parkinson's disease described with ICF classification. Int J Rehabil Res. 2011;34(2):141-50.

3. Tomlinson CL, Herd CP, Clarke CE, Meek C, Patel S, Stowe R, et al. Physiotherapy for Parkinson's disease: a comparison of techniques. Cochrane Database of Sys Rev.

2014(6):1-121.

4. Smania N, Picelli A, Geroin C, Ianes P, Marchina EL, Zenorini A, et al. Balance and gait rehabilitation in patients with Parkinson's disease. Diagnosis and Treatment of Parkinson's Disease. 2011:141-82.

5. Hulbert S, Ashburn A, Robert L, Verheyden G. A narrative review of turning deficits in people with Parkinson's disease. Disabil Rehabil. 2015;37(15):1382-9.

6. Mellone S, Mancini M, King LA, Horak FB, Chiari L. The quality of turning in Parkinson's disease: A compensatory strategy to prevent postural instability? J Neuroeng Rehabil. 2016;13:39-48.

7. Lohnes CA, Earhart GM. Saccadic eye movements are related to turning performance in Parkinson disease. J Parkinson Dis. 2011;1(1):109-18.

8. Reed-Jones RJ, Hollands MA, Reed-Jones JG, Vallis LA. Visually evoked wholebody turning responses during stepping in place in a virtual environment. Gait Posture. 2009;30(3):317-21.

9. Robins RK, Hollands MA. The effects of constraining vision and eye movements on whole-body coordination during standing turns. Exp Brain Res. 2017;235(12):3593603. 10. Hollands MA, Patla AE, Vickers JN. "Look where you're going!": Gaze behaviour associated with maintaining and changing the direction of locomotion. Exp Brain Res. 2002;143(2):221-30.

11. Huxham F, Baker R, Morris ME, Iansek R. Head and trunk rotation during walking turns in Parkinson's disease. Mov Disord. 2008;23(10):1391-7.

12. Ashburn A, Kampshoff C, Burnett M, Stack E, Pickering RM, Verheyden G. Sequence and onset of whole-body coordination when turning in response to a visual trigger: Comparing people with Parkinson's disease and healthy adults. Gait Posture. 2014;39(1):278-83.

13. Hulbert S, Ashburn A, Roberts L, Verheyden G. Dance for Parkinson's-The effects on whole body co-ordination during turning around. Complement Ther Med. 2017;32:91-7.

14. Jonasson SB, Nilsson MH, Lexell J, Carlsson G. Experiences of fear of falling in persons with Parkinson's disease - a qualitative study. BMC Geriatr. 2018;18(1):44-54.

15. Kader M, Iwarsson S, Odin P, Nilsson MH. Fall-related activity avoidance in relation to a history of falls or near falls, fear of falling and disease severity in people with Parkinson's disease. BMC Neurol. 2016;16:84-92.

16. Schenkman M, Butler RB. A model for multisystem evaluation treatment of individuals with Parkinson's disease. Phys Ther. 1989;69(11):932-43.

17. Schenkman ML, Morey M, Kuchibhatla M. Spinal flexibility and balance control among community-dwelling adults with and without Parkinson's disease. J Gerontrol Med Sci. 2000;55(8):441-45. 
18. Srivanitchapoom P, Pitakpatapee Y, Suengtaworn A. Parkinsonian syndromes: A review. Neurol India. 2018;66(Supplement):s15-s25.

19. Schenkman M, Cutson TM, Kuchibhatla M, Chandler J, Pieper CF, Ray L, et al. Exercise to improve spinal flexibility and function for people with Parkinson's disease: a randomized, controlled trial. J Am Geriatr Soc. 1998;46(10):1207-16.

20. Canning CG, Sherrington C, Lord SR, Fung VS, Close JC, Latt MD, et al. Exercise therapy for prevention of falls in people with Parkinson's disease: a protocol for a randomised controlled trial and economic evaluation. BMC Neurol. 2009;9:1-4.

21. Gobbi LT, Oliveira-Ferreira MD, Caetano MJ, Lirani-Silva E, Barbieri FA, Stella F, et al. Exercise programs improve mobility and balance in people with Parkinson's disease. Parkinsonism Relat Disord. 2009;15 Suppl 3:49-52.

22. Santos L, Fernandez-Rio J, Winge K, Barragan-Perez B, Gonzalez-Gomez L, Rodriguez-Perez V, et al. Effects of progressive resistance exercise in akinetic-rigid Parkinson's disease patients: a randomized controlled trial. Eur J Phys Rehabili Med. 2017;53(5):651-63.

23. Ni M, Hazzard JB, Signorile JF, Luca C. Exercise Guidelines for Gait Function in Parkinson's Disease: A Systematic Review and Meta-analysis. Neurorehabil Neural Repair. 2018;32(10):872-86.

24. Rawson KS, McNeely ME, Duncan RP, Pickett KA, Perlmutter JS, Earhart GM. Exercise and Parkinson disease: comparing tango, treadmill, and stretching. J Neurol Phys Ther. 2019;43(1):26-32.

25. Pohl P, Wressle E, Lundin F, Enthoven P, Dizdar N. Group-based music intervention in Parkinson's disease - findings from a mixed-methods study [with consumer summary]. Clin Rehabil. 2020;34(4):533-44.

26. Tomlinson CL, Patel S, Meek C, Herd CP, Clarke CE, Stowe R, et al. Physiotherapy versus placebo or no intervention in Parkinson's disease. Cochrane Database of Sys Rev. 2012;8:1-103.

27. Choi H-Y, Cho K-H, Jin C, Lee J, Kim T-H, Jung W-S, et al. Exercise therapies for Parkinson's Disease: a systematic review and meta-analysis. Parkinsonism Relat Disord. 2020;1-22.

28. Yang Y, Li XY, Gong L, Zhu YL, Hao YL. Tai Chi for improvement of motor function, balance and gait in Parkinson's disease: a systematic review and meta-analysis. PloS One. 2014;9(7):e102942-51.

29. Radder DLM, Lígia Silva de Lima A, Domingos J, Keus SHJ, van Nimwegen M, Bloem BR, et al. Physiotherapy in Parkinson's disease: a meta-analysis of present treatment modalities. Neurorehabil Neural Repair. 2020;34(10):871-80.

30. Shen X, Wong-Yu ISK, Mak MKY. Effects of exercise on falls, balance, and gait ability in Parkinson's aisease: a meta-analysis. Neurorehabil Neural Repair. 2016;30(6):512-27.

31. Arksey H, O'Malley L. Scoping studies: towards a methodological framework. Int J Soc Res Methodol. 2005;8(1):19-32.

32. Tricco AC, Lillie E, Zarin W, O'Brien KK, Colquhoun H, Levac D, et al. PRISMA extension for scoping reviews (prisma-scr): checklist and explanation the PRISMA-ScR statement. Ann Int Med. 2018;169(7):467-73.

33. Wroblewska A, Gajos A, Smyczynska U, Bogucki A. The therapeutic effect of nordic walking on freezing of gait in Parkinson's disease: a pilot study. Parkinsons Dis. 
2019;3846279-89.

34. Stozek J, Rudzinska M, Pustulka-Piwnik U, Szczudlik A. The effect of the rehabilitation program on balance, gait, physical performance and trunk rotation in Parkinson's disease. Aging Clin Exp Res. 2016 Dec;28(6):1169-77.

35. Solla P, Cugusi L, Bertoli M, Cereatti A, Della Croce U, Pani D, et al. Sardinian folk dance for individuals with Parkinson's Disease: a randomized controlled pilot trial. J Altern Complement Med. 2019;25(3):305-16.

36. Amano S, Nocera JR, Vallabhajosula S, Juncos JL, Gregor RJ, Waddell DE, et al. The effect of Tai Chi exercise on gait initiation and gait performance in persons with Parkinson's disease. Parkinsonism Relat Disord. 2013;19(11):955-60.

37. Park YJ. Effects of communal exercise with visual and auditory feedback provided by a smart application on gait ability and fear of falling in Parkinson's disease patients. J Exerc Rehabil. 2014;10(5):286-90.

38. Gao Q, Leung A, Yang Y, Wei Q, Guan M, Jia C, et al. Effects of Tai Chi on balance and fall prevention in Parkinson's disease: a randomized controlled trial. Clin Rehabil.

2014;28(8):748-53.

39. Nocera JR, Amano S, Vallabhajosula S, Hass CJ. Tai Chi exercise to improve nonmotor symptoms of Parkinson's disease. J Yoga Phys Ther. 2013;3:1-11.

40. Vergara-Diaz G, Osypiuk K, Hausdorff JM, Bonato P, Gow BJ, Miranda JG, et al. Tai Chi for reducing dual-task gait variability, a potential mediator of fall risk in Parkinson's disease: a pilot randomized controlled trial. Glob Adv Health Med. 2018;7: $1-12$.

41. Rios RS, Anang J, Fereshtehnejad SM, Pelletier A, Postuma R. Tango for treatment of motor and non-motor manifestations in Parkinson's disease: a randomized control study. Complement Ther Med. 2015;23(2):175-84.

42. Hubble RP, Silburn PA, Naughton GA, Cole MH. Trunk exercises improve balance in Parkinson disease: a phase II randomized controlled trial. J Neurol Phys Ther. 2019;43(2):96-105.

43. Fisher BE, Li QZ, Nacca A, Salema GJ, Song J, Yip J, et al. Treadmill exercise elevates striatal dopamine D2 receptor binding potential in patients with early Parkinson's disease. Neuroreport. 2013;24(10):509-14.

44. Reuter I, Mehnert S, Leone P, Kaps M, Oechsner M, Engelhardt M. Effects of a flexibility and relaxation programme, walking, and nordic walking on Parkinson's disease. J Aging Res. 2011;1-18.

45. Bombieri F, Schena F, Pellegrini B, Barone P, Tinazzi M, Erro RJP, et al. Walking on four limbs: a systematic review of Nordic Walking in Parkinson disease. Parkinsonism Relat Disord. 2017;38:8-12.

46. Schlenstedt C, Muthuraman M, Witt K, Weisser B, Fasano A, Deuschl G. Postural control and freezing of gait in Parkinson's disease. Parkinsonism Relat Disord. 2016;24:107-12.

47. Paula R, Teixeira-Salmela L, Faria C, Brito P, Cardoso F. Impact of an exercise program on physical, emotional, and social aspects of quality of life of individuals with Parkinson's disease. Move Disord. 2006;21(8):1073-77. 
48. Bartolo M, Serrao M, Tassorelli C, Don R, Ranavolo A, Draicchio F, et al. Fourweek trunk-specific rehabilitation treatment improves lateral trunk flexion in Parkinson's disease. Mov Disord. 2010;25(3):325-31.

49. Kanekar N, Aruin AS. Improvement of anticipatory postural adjustments for balance control: effect of a single training session. J Electromyogr Kinesiol. 2015;25(2):400-5. 50. Rochester L, Baker K, Hetherington V, Jones D, Willems AM, Kwakkel G, et al. Evidence for motor learning in Parkinson's disease: acquisition, automaticity and retention of cued gait performance after training with external rhythmical cues. Brain Res. 2010;1319:103-11.

51. Petzinger GM, Fisher BE, McEwen S, Beeler JA, Walsh JP, Jakowec MW. Exerciseenhanced neuroplasticity targeting motor and cognitive circuitry in Parkinson's disease. Lancet Neurol. 2013;12(7):716-26.

52. Abbruzzese G, Marchese R, Avanzino L, Pelosin E. Rehabilitation for Parkinson's disease: current outlook and future challenges. Parkinsonism Relat Disord. 2016;22:S604.

53. Hackney ME, Earhart GMJG, posture. Tai Chi improves balance and mobility in people with Parkinson disease. Disabil Rehabil. 2010;32(8):679-84.

54. Gao Q, Leung A, Yang Y, Wei Q, Guan M, Jia C, et al. Effects of Tai Chi on balance and fall prevention in Parkinson's disease: a randomized controlled trial. Clin Rehabil. 2014;28(8):748-53.

55. Lee MS, Lam P, Ernst EJP, disorders r. Effectiveness of tai chi for Parkinson's disease: a critical review. Parkinsonism Relat Disord. 2008;14(8):589-94.

56. Lam LC, Chan WM, Kwok TC, Chiu HF. Effectiveness of Tai Chi in maintenance of cognitive and functional abilities in mild cognitive impairment: a randomised controlled trial. Hong Kong Med J. 2014;20(3 Suppl 3):20-3.

57. Earhart GM. Dance as therapy for individuals with Parkinson disease. Eur J Phys Rehabil Med. 2009;45(2):231-8.

58. Hackney ME, Earhart GMJD, rehabilitation. Effects of dance on balance and gait in severe Parkinson disease: a case study. Gait Posture. 2008;28(3):456-60. 